\title{
Hemoglobin H Disease in Turkey: Experience from Eight Centers
}

\author{
Türkiye'de Hemoglobin H Hastalığl: Sekiz Merkezin Deneyimi
} \author{
Tayfur Toptaş9 \\ 1 Mersin University Faculty of Medicine, Department of Pediatric Hematology, Mersin, Turkey \\ ${ }^{2}$ Antakya Hemoglobinopathy Diagnosis, Control, and Education Center, Antakya, Turkey \\ ${ }^{3}$ Antakya Education and Research Hospital, Antakya, Turkey \\ 4 istanbul University Cerrahpaşa Faculty of Medicine, Department of Pediatric Hematology, Istanbul, Turkey \\ ${ }^{5}$ Gaziantep University Faculty of Medicine, Department of Pediatric Hematology, Gaziantep, Turkey \\ ${ }^{6}$ Dr. Sami Ulus Education and Research Hospital, Ankara, Turkey \\ 7TOBB University Faculty of Medicine, Department of Pediatric Hematology, Ankara, Turkey \\ ${ }^{8}$ Behçet Uz Education and Research Hospital, Izmir, Turkey \\ 9 Van Education and Research Hospital, Van, Turkey
}

Selma Ünal1, Gönül Oktay², Can Acıpayam³, Gül Illhan³, Edip Gali22, Tiraje Celkan4, Ali Bay5, Barış Malbora6, Nejat Akar7, Yeşim Oymak8,

\section{Abstract}

The purpose of this study was to research the problem of hemoglobin $\mathrm{H}(\mathrm{HbH})$ disease, to reveal the distribution patterns among different health centers, and to emphasize the importance of this disease for Turkey. A total of 273 patients were included from 8 hemoglobinopathy centers. The Antakya Hemoglobinopathy Center reported 232 patients and the remaining 7 centers reported 41 patients. PubMed was also searched for published articles related to Turkish patients with $\mathrm{HbH}$ disease, and we found 16 articles involving a total of $198 \mathrm{HbH}$ patients. Most of the patients were reported from Antakya; thus, special attention should be paid to this region. This is a preliminary study to investigate the extent of the problem of $\mathrm{HbH}$ disease and it emphasizes the need for hematology associations or the Ministry of Health to record all cases of $\mathrm{HbH}$ disease in Turkey.

Keywords: Thalassemia, Hemoglobinopathy, Hemoglobin H disease

\section{Öz}

$\mathrm{Bu}$ çalışmada, ülkemizdeki hemoglobin $\mathrm{H}(\mathrm{HbH})$ hastalığı sorununu irdelemek, bölgelere göre dağılımını tespit etmek ve sonuç olarak $\mathrm{HbH}$ hastalığının ülkemiz için önemini vurgulamak amaçlandı. Sekiz hemoglobinopati merkezinden toplam 273 hasta çalışmaya dahil edildi. Merkezler arasında en fazla bildirimi 232 hasta ile Antakya Hemoglobinopati Merkezi sağladı. Kalan 7 merkezden toplam 41 $\mathrm{HbH}$ hastası bildirildi. Eş zamanlı olarak PubMed'den Türkiye'den yayınlanan ya da Türk $\mathrm{HbH}$ hastalarının dahil edildiği makaleler araştırıldı ve sonuçta $198 \mathrm{HbH}$ hastasını içeren toplam 16 yayına ulaşıldı. Bu çalışma, ülkemizde $\mathrm{HbH}$ hastalığı sorununu araştıran bir ön çalışmadır. Çalışmamıza Antakya'dan oldukça fazla hasta bildiriminin olması $\mathrm{HbH}$ hastalığı yönünden dikkatimizi bu bölgeye yöneltmemize neden olacaktır. Sağlık Bakanlığı önderliğinde oluşturulacak kayıt sistemleri ile tüm HbH'li hastalar kayıt altına alınmalı ve böylece $\mathrm{HbH}$ hastalığının ülkemiz için önemi vurgulanmalıdır.

Anahtar Sözcükler: Talasemi, Hemoglobinopati, Hemoglobin H hastalığı

\section{Introduction}

Hemoglobin $\mathrm{H}(\mathrm{HbH})$ disease occurs due to defects in 3 of the 4 alpha genes found in healthy people. $\mathrm{HbH}(--/-\alpha)$ is compatible with life and usually has a similar presentation to that of thalassemia intermedia [1]. However, clinical signs vary among patients, and while some patients may need intermittent or frequent transfusions, others do not.
$\mathrm{HbH}$ disease is suspected in cases of unresponsiveness to iron replacement therapy and findings of microcytic anemia in complete blood counts and peripheral smears. In the early decades of the disease, most patients do not need erythrocyte transfusions. Diagnosis is established when $5 \%-30 \% \mathrm{HbH}$ is detected on $\mathrm{Hb}$ electrophoresis. Patients with $\mathrm{HbH}$ disease also have 20\%-40\% $\mathrm{Hb}$ Barts in the evaluation of cord blood [2]. Brilliant cresyl staining can be used as a screening procedure where the molecular diagnosis of $\mathrm{HbH}$ disease is not possible [3]. 
The prevalence of alpha thalassemia is $0.24 \%$ worldwide and 13,000 babies with $\mathrm{HbH}$ are born annually [4]. The overall incidence rate of alpha thalassemia for Turkey is reported to be $0.25 \%-4.1 \%[5,6,7]$. However, according to different singlecenter studies from the south of Turkey, the frequency of alpha thalassemia ranges between $2.5 \%$ and $7.5 \%[4,5,6,7,8,9,10,11,12]$.

As the incidence of alpha thalassemia is high, the prevalence of $\mathrm{HbH}$ disease may be assumed to be higher. However, due to inadequate reporting of patients with $\mathrm{HbH}$ disease, the exact spread and occurrence rates of $\mathrm{HbH}$ disease cannot be determined. Thus, the patients who were reported from eight different centers and those reported from previously published studies related to Turkish cases of $\mathrm{HbH}$ disease were included in the present study.

\section{Materials and Methods}

Hemoglobinopathy centers in Turkey were informed about and invited to participate in this study. Eight centers accepted the invitation and 273 patients were included in the study. Three of these centers were university hospitals and the others were state hospitals. The Antakya Hemoglobinopathy Diagnosis, Control, and Education Center (AHDCEC) reported 232 patients. The remaining 41 patients were reported from the other 7 centers. All of the data collected from these centers were evaluated retrospectively. Additionally, PubMed was searched for English publications related to Turkish patients with $\mathrm{HbH}$ disease. As publications in Turkish were difficult to locate and access, those sources were not included.

\section{Results}

Of the 273 patients included in the study, 125 were female and 148 were male. Their ages ranged between 9 month and 78 years (Table 1). Mean Hb level was $8.7 \mathrm{~g} / \mathrm{dL}$ (range: 7.2-10.9), mean red blood cell count was 5.16 ( $\times 10^{12 / L) ~(r a n g e: ~ 4.07-5.8), ~ m e a n ~}$ MCV was $54.7 \mathrm{fL}$ (range: 48-76.4), mean $\mathrm{MCH}$ value was $17.9 \mathrm{pg}$ (range: 15-23.9), mean MCHC value was $32.2 \mathrm{~g} / \mathrm{dL}$ (range: 28.434), mean RDW value was 26.7 (range: 14.6-28), mean HbA2 was $2 \%$ (range: $1.2 \%-2.8 \%$ ), mean $\mathrm{HbF}$ was $2.9 \%$ (range: $0.2 \%-$ $3.3 \%$ ), and mean $\mathrm{HbH}$ was $4.7 \%$ (range: $1.8 \%-17.9 \%$ ).

The AHDCEC reported 232 patients with $\mathrm{HbH}$ disease who were recorded in a data file reporting cases dating back to as far as 1993. In the evaluation of the patients from the AHDCEC, it was observed that the diagnosis of $\mathrm{HbH}$ disease was based on clinical findings, hemoglobin electrophoresis, and $\mathrm{HbH}$ detection, but alpha gene mutation analysis was not performed for any of these patients. The evaluation of data from 41 patients from the centers other than the AHDCEC revealed that only one patient reached adulthood with an age of 58. Premarital screening was performed in only one family and one other family had a history of hydrops fetalis. The centers contributing to the study and the numbers of patients from these centers are shown in Table 1.

The PubMed search for publications on Turkish patients with $\mathrm{HbH}$ disease yielded 16 articles with a total of 198 patients with $\mathrm{HbH}$ disease (Table 2) $[10,13,14,15,16,17,18,19,20,21,22,23,24$, $25,26,27]$.

\section{Discussion}

Although reports about patients with beta thalassemia and sickle cell anemia are available, insufficient data exist about patients with $\mathrm{HbH}$ disease, which can be accompanied by various complications and moderate or severe anemia that may require transfusions.

A total of 273 patients from 8 centers were included in this study and 232 of these patients were from Antakya, which is located in the Mediterranean region and had high malaria incidence rates,

\begin{tabular}{|c|c|c|c|}
\hline Center & $\begin{array}{l}\text { Reported } \\
\text { Number of } \\
\text { Patients } \\
(n=273)\end{array}$ & Age & Sex \\
\hline Antakya Hemoglobinopathy Diagnosis, Control, and Education Center & 232 & $2-78$ years & $\begin{array}{l}112 \text { Female/ } \\
120 \text { Male }\end{array}$ \\
\hline
\end{tabular}




\begin{tabular}{|l|l|l|}
\hline Table 2. Articles associated with hemoglobin H disease in Turkey. & References \\
\hline Reported Center & Number of Patients & {$[14,15,16,18,19,22,23,26]$} \\
\hline Hacettepe University Faculty of Medicine & 138 & {$[13,17,20,27]$} \\
\hline İstanbul University Faculty of Medicine & 18 & {$[20,21,25]$} \\
\hline Çukurova University Faculty of Medicine & 39 & {$[24]$} \\
\hline Ege University Faculty of Medicine & 1 & {$[10]$} \\
\hline Mustafa Kemal University Faculty of Medicine & 2 & \\
\hline Total number of patients & 198 & \\
\hline
\end{tabular}

probably due to Lake Amik, until recent years. It is known that alpha thalassemia is common where malaria is endemic. It has been observed that another reason why the majority of patients with $\mathrm{HbH}$ disease are reported from this area is that the doctors dealing with thalassemia have been working in the region for many years, and thalassemia patients have been recorded since 1993 at the AHDCEC. The low reported number of patients from cities within the same geographic region, such as Mersin and other centers of population, may be due to the recent start of recording patients with thalassemia and $\mathrm{HbH}$ disease.

We detected 198 patients with $\mathrm{HbH}$ disease when we searched articles from PubMed related to Turkish patients with $\mathrm{HbH}$ disease $[10,13,14,15,16,17,18,19,20,21,22,23,24,25,26,27]$. When the results of our study were added to that number, we found 471 $\mathrm{HbH}$ cases to date from Turkey, and this number is fairly high (Table 2). Since the origin of the patients was not recorded in other published studies, no other region was pointed out like Antakya where $\mathrm{HbH}$ disease was very frequent.

As the data used in this study were not obtained from every center in Turkey, this does not accurately reflect the real number of patients and data on $\mathrm{HbH}$ disease in Turkey. However, as many of the $\mathrm{HbH}$ patients were reported from Antakya, the situation of the disease in this particular region deserves attention first. In addition, it is necessary to design studies using the data from all centers in Turkey to determine the exact number of patients with $\mathrm{HbH}$ disease.

Another important point is that cases of hydrops fetalis due to alpha thalassemia are rarely reported in Turkey [28]. All cases should be reported and families with $\mathrm{HbH}$ should be evaluated for their history of nonimmunological hydrops fetalis. Prenatal diagnosis should be offered to families who have history of hydrops fetalis, in utero death, or abortion.

\section{Conclusion}

There are no exact data related to the prevalence of $\mathrm{HbH}$ disease in Turkey. However, the 471 cases that are reported based on the data from the literature and the eight centers included in this study are noteworthy. Thalassemia is very common in Turkey, and there are several centers to follow the disease. Recording of $\mathrm{HbH}$ cases by these centers will illustrate the urgency of the thalassemia problem in Turkey.
In this study, it was found that Antakya is the region where $\mathrm{HbH}$ disease is most frequently encountered in Turkey. More studies are required to understand the facts about alpha thalassemia$\mathrm{HbH}$ disease in Turkey.

\section{Authorship Contributions}

Concept: Selma Ünal, Design: Selma Ünal, Data Collection or Processing: Selma Ünal, Gönül Oktay, Can Acıpayam, Gül İlhan, Edip Gali, Tiraje Celkan, Ali Bay, Barış Malbora, Nejat Akar, Yeşim Oymak, Tayfur Toptaş, Analysis or Interpretation: Selma Ünal, Literature Search: Selma Ünal, Writing: Selma Ünal.

Conflict of Interest: The authors of this paper have no conflicts of interest, including specific financial interests, relationships, and/or affiliations relevant to the subject matter or materials included.

\section{References}

1. Chui DH, Fucharoen $\mathrm{S}$, Chan V. Hemoglobin $\mathrm{H}$ disease: not necessarily a benign disorder. Blood 2003;103:791-800.

2. Steinberg MH, Forget BG, Higgs DR, Weatherall DJ. Disorders of Hemoglobin. 2nd ed. Cambridge, Cambridge University, 2009.

3. Kulaç I, Ünal Ş, Gümrük F. Brilliant cresyl blue staining for screening hemoglobin H disease: reticulocyte smear. Turk J Hematol 2009;26:45.

4. Canatan D, Oğuz N, Güvendik I, Yıldırım S. The incidence of alphathalassemia in Antalya-Turkey. Turk J Haematol 2002;19:433-434.

5. Ozsoylu S, Malik SA. Incidence of alpha thalassemia in Turkey. Turk J Pediatr 1982;24:235-244.

6. Fei YJ, Kutlar F, Harris HF, Wilson MM, Milana A, Sciacca P, Schiliro G, Masala B, Manca L, Altay C. A search for anomalies in the zeta, alpha, beta, and gamma globin gene arrangements in normal black, Italian, Turkish, and Spanish newborns. Hemoglobin 1989;13:45-65.

7. Arcasoy A. Türkiye'de Thalassemia Taşıyıcı Sıklığı. Ankara, Turkey: Ankara Thalassemia Derneği, 1991 (in Turkish).

8. Kılınç Y. Hemoglobinopathies in Turkey. Turk J Hematol 2006;23:214-216.

9. Polat G, Yuregir GT, Aksoy K. Detection of deletional alpha thalassemia in Cukurova. Ann Med Sci 1998;7:14-17.

10. Celik MM, Gunesacar R, Oktay G, Duran GG, Kaya H. Spectrum of $\alpha$-thalassemia mutations including first observation of (FIL) deletion in Hatay Province, Turkey. Blood Cells Mol Dis 2013;51:27-30.

11. Aldemir Ö, İzmirli M. Hataydaki $\alpha$-talasemi genotipleri ve $\alpha$-talasemi genotip frekansı. Abant Med J 2014;3:233-236 (in Turkish).

12. Kılınç $Y$, Kümi $M$, Gürgey $A$, Altay Ç. Adana bölgesinde doğan bebeklerde kordon kanı çalısması ile alfa talasemi, G6PD enzim eksikliği ve HbS sıklığının araştırılması. Doğa Tıp ve Ecz Der 1986;10:162 (in Turkish).

13. Aksoy $\mathrm{M}$, Erdem $\mathrm{S}$. Haemoglobin $\mathrm{H}$ disease study of an Eti-Turk family. Acta Genet Stat Med 1968;18:12-22. 
14. Ozsoylu S, Isik K. Haemoglobin $\mathrm{H}$ disease in a Turkish family. Scand J Haematol 1973;10:54-58.

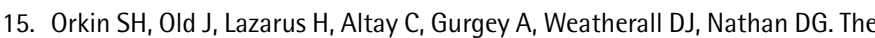
molecular basis of alpha-thalassemias: frequent occurrence of dysfunctional alpha loci among non-Asians with $\mathrm{Hb} \mathrm{H}$ disease. Cell 1979;17:33-42.

16. Altay C, Gurgey A, Tuncbilek E. Hematological evaluation of patients with various combinations of alpha-thalassemia. Am J Hematol 1980;9:261-267.

17. Aksoy M, Kutlar A, Kutlar F, Harano T, Chen SS, Huisman TH. Hemoglobin $\mathrm{H}$ disease in two Turkish females and one Iranian newborn. Hemoglobin 1985;9:373-384.

18. Kutlar F, Gonzalez-Redondo JM, Kutlar A, Gurgey A, Altay C, Efremov GD, Kleman K, Huisman TH. The levels of zeta, gamma, and delta chains in patients with Hb H disease. Hum Genet 1989;82:179-186.

19. Fei YJ, Oner R, Bozkurt G, Gu LH, Altay C, Gurgey A, Fattoum S, Baysal E, Huisman TH. Hb $\mathrm{H}$ disease caused by a homozygosity for the AATAAA-$>$ AATAAG mutation in the polyadenylation site of the alpha 2-globin gene: hematological observations. Acta Haematol 1992;88:82-85.

20. Yüregir GT, Aksoy K, Çürük MA, Dikmen N, Fei YJ, Baysal E, Huisman TH. Hb $\mathrm{H}$ disease in a Turkish family resulting from the interaction of a deletional $\alpha$-thalassemia- 1 and a newly discovered poly A mutation. Br J Haematol 1992;80:527-532.

21. Cürük MA, Dimovski AJ, Baysal $E, G u$ LH, Kutlar $F$, Molchanova TP, Webber BB, Altay C, Gürgey A, Huisman TH. Hb Adana or $\alpha 2(59)(E 8) G l y-->A s p \beta 2$, a severely unstable $\alpha 1$-globin variant, observed in combination with the $-(\alpha) 20.5 \mathrm{~KB} \alpha$-thal-1 deletion in two Turkish patients. Am J Hematol 1993;44:270-275.

22. Oner C, Gürgey $A$, Oner $R$, Balkan $H$, Gümrük $F$, Baysal $E$, Altay $C$. The molecular basis of $\mathrm{Hb} \mathrm{H}$ disease in Turkey. Hemoglobin 1997;21:41-51.

23. Oner $C$, Oner R, Birben E, Balkan $H$, Gümrük F, Gürgey A, Altay C. HB H disease with homozygosity for red cell G6PD deficiency in a Turkish female. Hemoglobin 1998;22;157-160.

24. Durmaz AA, Akin H, Ekmekci AY, Onay H, Durmaz B, Cogulu O, Aydinok $Y$, Ozkinay F. A severe $\alpha$ thalassemia case compound heterozygous for $\mathrm{Hb}$ Adana in $\alpha 1$ gene and $20.5 \mathrm{~kb}$ double gene deletion. J Pediatr Hematol Oncol 2009;31:592-594.

25. Cürük MA. Hb H ( $\beta 4)$ disease in Cukurova, southern Turkey. Hemoglobin 2007;31:265-271.

26. Ünal Ş, Gümrük F. The hematological and molecular spectrum of alpha thalassemias in Turkey: the Hacettepe experience. Turk J Hematol 2015;32:136-143.

27. Karakas Z, Koc B, Temurhan $S$, Elgun $T$, Karaman $S$, Asker G, Gencay G, Timur Ç, Yıldırmak ZY, Celkan T, Devecioglu Ö, Aydın F. Evaluation of alpha thalassemia mutations in cases with hypochromic microcytic anemia: Istanbul perspective. Turk J Hematol 2015.

28. Gurgey A, Altay C, Beksaç MS, Bhattacharya R, Kutlar F, Huisman TH. Hydrops fetalis due to homozygosity for alpha-thalassemia-1, -(alpha)-20.5 kb: the first observation in a Turkish family. Acta Haematol 1989;81:169171. 